\title{
THE RISE OF COMMUNITY ENERGY \\ FROM GRASSROOTS TO MAINSTREAM: \\ THE ROLE OF LAW AND POLICY
}

\section{Annalisa Savaresi*}

\begin{abstract}
In recent years, national and subnational law-makers and policy-makers have increasingly adopted measures to stimulate decentralised renewable energy generation, turning local and rural communities into prominent actors in the energy transition. The recast of the EU Renewable Energy Directive follows this trend, prompting all EU Member States to adopt measures to spearhead community energy. Yet to date, only a handful of 'pioneer' EU Member States - most saliently Denmark, Germany and the UK - have accrued significant experience with the mainstreaming of community energy. This article reflects on the role of law and policy in turning grassroots community action into a mainstream means for renewable energy generation. It unpacks the regulatory questions underlying the notion of community energy embedded in the Renewables Directive, looking at how these have been addressed in pioneer Member States. This analysis aims to deliver greater understanding of community energy, to highlight gaps in our knowledge of it, and ultimately to identify an agenda for further scholarly enquiry.
\end{abstract}

KEYWORDS: community energy, renewable energy, energy transition, climate change

\footnotetext{
* Lecturer in Environmental Law, University of Stirling, UK. Email: annalisa.savaresi@ stir.ac.uk
}

This is a pre-copyedited, author-produced PDF of an article accepted for publication in Journal of Environmental Law following peer review. The version of record Savaresi A (2019) The Rise of Community Energy from Grassroots to Mainstream: The Role of Law and Policy. Journal of Environmental Law, 31 (3), pp. 487-510 is available online at https://doi.org/10.1093/jel/eqz006 


\section{Introduction}

The fight against climate change requires replacing fossil fuel-based energy generation technologies with renewable ones, ${ }^{1}$ while at the same time pursuing the Sustainable Development Goal to 'ensure access to affordable, reliable, sustainable, and modern energy for all'. ${ }^{2}$ The quest for the tools to deliver this clean energy transition raises questions on the ways in which change is enacted, and the role of law and policy in this context. Reliance on fossil-fuel based energy generation and the related energy governance arrangements undoubtedly created winners and losers, but changing the status quo entails finding new equilibria, ${ }^{3}$ engendering change at the pace and scale needed. ${ }^{4}$ Polycentric, ${ }^{5}$ bottom-up ${ }^{6}$ approaches have increasingly been advocated for as means to deliver a democratic and inclusive energy transition.

In this fast moving and increasingly decentralised energy landscape, local and rural communities have unwittingly become protagonists of the energy transition. The term 'community energy' is commonly used to identify situations in which communities are involved in the production of renewable energy, regardless of the type of technology deployed. The literature often rather optimistically portrays community energy as a means to engender greater legitimacy and democratisation in energy governance, ${ }^{7}$ tackle energy poverty, ${ }^{8}$ and achieve greater 'energy justice'. ${ }^{9}$

${ }^{1}$ According to the International Renewable Energy Agency (IRENA) the share of the energy mix coming from renewables is expected to rise to $21 \%$ by 2030 , IRENA, 'REthinking Energy 2017 : Accelerating the Global Energy Transformation' (IRENA 2017) 23-24.

2 Transforming Our World: The 2030 Agenda for Sustainable Development, UN Doc A/RES/70/1 (25 September 2015) 54.

${ }^{3}$ See Ioan Fazey and others, 'Transformation in a Changing Climate: A Research Agenda' (2017) 9 Climate and Development 1, 10.

${ }^{4}$ See Laurence Delina and Benjamin Sovacool, 'Of Temporality and Plurality: An Epistemic and Governance Agenda for Accelerating Just Transitions for Energy Access and Sustainable Development' (2018) 34 Current Opinion in Environmental Sustainability 1.

${ }^{5}$ This term is famously used in the works of Elinor Ostrom, Governing the Commons, the Evolution of Institutions for Collective Action (CUP 1990). In the context of the energy transition, see Andreas Goldthau and Benjamin Sovacool, 'The Uniqueness of the Energy Security, Justice, and Governance Problem' (2012) 41 Energy Policy 232, 234.

${ }^{6}$ See for example the use of this term in Marjan Peeters and Thomas Schomerus, Renewable Energy Law in the EU: Legal Perspectives on Bottom-up Approaches (Edward Elgar Publishing 2014).

${ }^{7}$ See for example Tineke van der Schoor and Bert Scholtens, 'Power to the People: Local Community Initiatives and the Transition to Sustainable Energy' (2015) 43 Renewable and Sustainable Energy Reviews 666; Soren Becker and Conrad Kunze, 'Transcending Community Energy: Collective and Politically Motivated Projects in Renewable Energy (CPE) across Europe' (2014) 8 People Place and Policy 180; Matthew Burke and Jennie Stephens, 'Energy Democracy: Goals and Policy Instruments for Sociotechnical Transitions' (2017) 33 Energy Research \& Social Science 35. 
Schlosberg even suggests that community energy may be regarded as a manifestation of 'sustainable materialism', embodying resistance to power, coupled with a 'postmaterialist' approach to energy production, characterised by a concern for the environment. ${ }^{10}$

Although energy democratisation, decentralisation and even independence ${ }^{11}$ are undoubtedly desirable objectives, the widespread uptake of community energy requires significant structural adjustment to governance systems built around largescale energy production and distribution. ${ }^{12}$ The push towards this structural adjustment underlies the recast of the EU Renewable Energy Directive (Renewables Directive) - one of the cornerstones of EU climate and energy policy and a key means to enable the energy transition in the EU. ${ }^{13}$ The recast Directive includes for the first time provisions to stimulate the formation of 'renewable energy communities' in all EU Member States, to be implemented by $2021 .^{14}$ These provisions largely leave it to national and subnational law-makers and policy-makers to address the manifold regulatory complexities associated with moving community energy from grassroots to mainstream. Measures promoting community energy are expected to be included also in the recast Directive on Common Rules for the Internal Market in Electricity, currently under preparation. ${ }^{15}$ However, only a few Member States - most saliently, Denmark, Germany and the UK, and within the UK, Scotland - have already accrued significant regulatory experience with the mainstreaming of community energy. ${ }^{16}$ The

\footnotetext{
${ }^{8}$ See for example Rob W Saunders, Robert JK Gross and Joanne Wade, 'Can Premium Tariffs for Micro-Generation and Small Scale Renewable Heat Help the Fuel Poor, and If So, How? Case Studies of Innovative Finance for Community Energy Schemes in the UK' (2012) 42 Energy Policy 78.

${ }^{9}$ See for example Kirsten Jenkins and others, 'Energy Justice: A Conceptual Review' (2016) 11 Energy Research \& Social Science 174, 177.

${ }^{10}$ David Schlosberg and Romand Coles, 'The New Environmentalism of Everyday Life: Sustainability, Material Flows and Movements' (2016) 15 Contemporary Political Theory 160.

${ }^{11}$ See for example Benjamin Sovacool, 'Energy Policymaking in Denmark: Implications for Global Energy Security and Sustainability' (2013) 61 Energy Policy 829; Bill Slee and Jelte Harnmeijer, 'Community Renewables: Balancing Optimism with Reality' in Geoffrey Wood and Keith Baker (eds), A Critical Review of Scottish Renewable and Low Carbon Energy Policy (Palgrave Macmillan 2017) 37-39.

12 Joseph Tomain, Clean Power Politics: The Democratization of Energy (CUP 2017) 204.

${ }^{13}$ Directive 2018/2001 of the European Parliament and of the Council on the promotion of the use of energy from renewable sources, [2018] OJ L328/82 [Recast Renewables Directive].

14 ibid Article 4.8.

${ }^{15}$ The proposal for a directive on common rules for the internal market in electricity COM/2016/0864 (2016) recasts Directive 2009/72/EC. Since the drafting process of the directive's text remains ongoing at the time of writing, the present article only focuses on the provisions on community energy in the recast Renewables Directive.

${ }^{16}$ See for example Colin Nolden, 'Governing Community Energy-Feed-in Tariffs and the Development of Community Wind Energy Schemes in the United Kingdom and Germany' (2013) 63
} 
evidence emerging from these States suggests that there are regulatory complexities associated with the mainstreaming of community energy, which are not easy to resolve. ${ }^{17}$

Much literature points to the need for greater reflection on the role of law and policy in this connection. ${ }^{18}$ Yet little legal scholarship has looked at this matter to date. ${ }^{19}$ At a time when the EU is spearheading community energy, a scholarly reflection on the regulatory experience of Member States that may be regarded as pioneers in this field is particularly timely. Lessons learnt from the implementation of measures stimulating community energy are expected to be useful for all states looking at bolstering citizens' involvement in renewable energy generation, both within and outside the EU. This is therefore a critical moment to examine and consolidate what we know about community energy, to understand what works, when, and why.

The present article sets out to address this gap in the literature. The objective is to paint a picture of what we know already on the role of law and policy in facilitating the uptake of community energy, mapping existing knowledge and highlighting areas for further research. The aim is not so much to challenge the use of

Energy Policy 543; Marieke Oteman, Mark Wiering and Jan-Kees Helderman, 'The Institutional Space of Community Initiatives for Renewable Energy: A Comparative Case Study of the Netherlands, Germany and Denmark' (2014) 4 Energy, Sustainability and Society 11; ClientEarth and Community Power, 'Community Power: Model Legal Frameworks for Citizen-owned Renewable Energy' (ClientEarth 2014) https://ec.europa.eu/energy/intelligent/projects/sites/ieeprojects/files/projects/documents/model_legal_frameworks_2014.pdf accessed 29 January 2019; British Academy, 'Community Energy Generation' (British Academy 2016) http://www.britac.ac.uk/policy/Energypolicy.cfm accessed 25 January 2019; Frank Geels and others, 'The Enactment of Socio-Technical Transition Pathways: A Reformulated Typology and a Comparative Multi-Level Analysis of the German and UK Low-Carbon Electricity Transitions (19902014)' (2016) 45 Research Policy 896.

${ }^{17}$ See Aileen McHarg, 'Community Benefit Through Community Ownership of Renewable Generation in Scotland: Power to the People?' in Lila Barrera-Hernandez and others (eds), Sharing the Costs and Benefits of Energy and Resource Activity (OUP 2016); Anita Rønne, 'Opposition to Wind Farms and Possible Responses of the Legal System' in Lila Barrera-Hernandez and others (eds), Sharing the Costs and Benefits of Energy and Resource Activity: Legal Change and Impact on Communities (OUP 2016); Marie Leer Jørgensen, 'Compensation Schemes and Distributive Fairness in Wind Energy Projects' (European Environmental Law Forum Annual Conference, Copenhagen, 2017) http://law.au.dk/fileadmin/Jura/dokumenter/forskning/EELF/MARIE_LEER_ 31.08.pdf accessed 25 January 2018.

${ }^{18}$ See for example Bill Slee, 'Is There a Case for Community-Based Equity Participation in Scottish on-Shore Wind Energy Production? Gaps in Evidence and Research Needs' (2015) 41 Renewable and Sustainable Energy Reviews 540; Richard Cowell and Patrick Devine-Wright, 'A "Delivery-Democracy Dilemma"? Mapping and Explaining Policy Change for Public Engagement with Energy Infrastructure' (2018) 20 J of Env Policy \& Planning 499; Franziska Mey and Mark Diesendorf, 'Who Owns an Energy Transition? Strategic Action Fields and Community Wind Energy in Denmark' (2018) 35 Energy Research \& Social Science 108, 115.

${ }^{19}$ With the sole possible exception of McHarg (n 17). 
community energy as a means to engender the energy transition. Rather more modestly, this article strives to improve understanding of what law- and policymakers can do in order to support community energy, addressing the challenges and averting the perverse outcomes experienced by early movers.

In order to develop a greater understanding of the regulatory landscape that has enabled the mainstreaming of community energy, this article couples the analysis of law and policies in pioneer EU Member States with a review of literature from the social sciences. ${ }^{20}$ Pursuant to a comparative socio-legal approach, the differences and similarities between laws and policies in pioneer countries are scrutinised in light of social sciences literature on the implementation of the said laws and policies. This desk-based study was combined with participant observation at selected public meetings where the implementation of community energy policies was discussed, and informal interviews with community actors, businesses and professionals supporting community energy projects. ${ }^{21}$ While not quantitatively representative, real-life observation and informal interviews were an important complement to developing the understanding, expounded in this article, of how community energy policies work in practice.

The remainder of the article is divided into three parts. The first considers the complexities underling the very notion of community energy, both in the literature and in practice. The second section unpacks the regulatory questions associated with community energy, looking at how these have been addressed in the recast Renewables Directive and in pioneer Member States, and flagging the challenges experienced. The conclusion reflects on what we know already about the role of law and policy in making community energy happen, highlighting gaps in knowledge that require further research.

\section{Defining Community Energy}

\footnotetext{
${ }^{20}$ As suggested also in Roger Cotterell, 'Why Must Legal Ideas Be Interpreted Sociologically?' (1998) 25 JLS 171.

${ }^{21}$ The public events include the 2015-2017 editions of the Community and Renewable Energy Scheme Conference, held in Stirling; and the 2017 Local Energy Challenge Fund Showcase, held in Glasgow; as well as side-events on community energy held at the Conferences of the Parties to the UN Framework Convention on Climate Change in the same years.
} 
The term community energy is of fairly recent coinage, but has rapidly gained traction both in policy and scholarship parlance. In one of the earliest conceptualisations, Walker and Devine-Wright distinguish between process (who a given project is owned and managed by) and outcome (who benefits from the project). ${ }^{22}$ From the perspective of process, they argue, what matters is who a renewable energy project 'is developed and run by' and 'who is involved and has influence'. ${ }^{23}$ From the perspective of outcome, conversely, what matters is 'how the outcomes of a project are spatially and socially distributed' and 'who benefits from it in economic or social terms. ${ }^{24}$ So a community may own a renewable energy generation plant and benefit from it, or, conversely, a community may not own the plant, but still benefit from it. This definition emphasises, on the one hand, a degree of community agency, ${ }^{25}$ and on the other, an element of community recipience of advantages from projects in which they are not necessarily actively engaged with. It is possible furthermore to distinguish between cases where a community takes the initiative and establishes a joint venture with a commercial developer (proactive shared ownership); and cases where members of a given community are simply offered the possibility to purchase shares in a project led by a commercial developer (reactive shared ownership).

This conceptualisation largely builds on the grassroots origin of community energy, and has greatly influenced subsequent literature, ${ }^{26}$ as well as substantive policy developments. ${ }^{27} \mathrm{Law}$ and policy documents on community energy, ${ }^{28}$ however, largely focus on process, rather than outcome, and define community energy projects

${ }^{22}$ Gordon Walker and Patrick Devine-Wright, 'Community Renewable Energy: What Should It Mean?' (2008) 36 Energy Policy 497, 498.

23 Ibid.

${ }^{24}$ Ibid.

${ }^{25}$ As noted also in ClientEarth (n 16) 31.

${ }^{26}$ See for example Gill Seyfang and Alex Haxeltine, 'Growing Grassroots Innovations: Exploring the Role of Community-Based Initiatives in Governing Sustainable Energy Transitions' (2012) 30 Environment and Planning C: Government and Policy 381; Mhairi Aitken, Claire Haggett and David Rudolph, 'Wind Farms Community Engagement Good Practice Review' (ClimateXchange 2014); Claire Haggett and Mhairi Aitken, 'Grassroots Energy Innovations: The Role of Community Ownership and Investment' (2015) 2 Current Sustainable/Renewable Energy Reports 98; McHarg (n 17) $301-305$.

${ }^{27}$ See for example UK Department for Energy and Climate Change (DECC), Community Energy Strategy (2014) 47; Scottish Government, Community Energy Policy Statement (2015) 6.

${ }^{28}$ See for example, for England: DECC (n 27); and DECC, Community Engagement for Onshore Wind Developments: Best Practice Guidance for England, 2014. For Scotland: Scottish Government (n 27); and Scottish Government, Good Practice Principles for Shared Ownership of Onshore Renewable Energy Developments (2015). 
as those where communities own, in full or in part, energy generation plants. ${ }^{29}$ The notion of community energy in regulatory practice, therefore, does not merely entail that local residents be heard, or receive so-called benefit packages, but rather centres on communities' partial or total ownership and management of renewable energy generation plants.

This understanding is manifest also in the 2018 recast Renewables Directive. ${ }^{30}$ The Directive is a key piece of EU climate change policy and of the Energy Union, which envisions a central role for citizens in the energy transition away from fossil fuels. ${ }^{31}$ As such, it is unsurprising that the Directive includes specific provisions to stimulate the formation of 'renewable energy communities', which it defines as a 'legal entity':

a) which, in accordance with the applicable national law, is based on open and voluntary participation, is autonomous, and is effectively controlled by shareholders or members that are located in the proximity of the renewable energy projects owned and developed by that legal entity;

b) the shareholders or members of which are natural persons, SMEs or local authorities, including municipalities;

c) the primary purpose of which is to provide environmental, economic or social community benefits for its shareholders or members or for the local areas where it operates, rather than financial profits. ${ }^{32}$

The criteria to identify community energy projects listed in the Directive revolve around the nature of shareholders and the purpose of the endeavour. They bundle together a diverse set of actors, encapsulating projects whose shareholders or members are natural persons, local authorities, including municipalities, or Small and Medium Enterprises (SMEs). ${ }^{33}$ As a result, diverse entities fall within the scope of the notion of community energy drawn up by the Directive, such as, for example, a biomass power plant partially owned and run by a local council, or a wind farm wholly owned by a remote island community. What meaning will be attached to the expression 'effective control' in practice remains to be seen. Different criteria including, for example, a 51\% community ownership requirement - were considered

${ }^{29}$ See for example DECC, Community Energy Strategy (2014) 47; Scottish Government, Community Energy Policy Statement (2015) 6. This observation is also made in ClientEarth (n 16) 5.

${ }^{30}$ Recast Renewables Directive (n 13).

${ }^{31}$ See Communication from the Commission to the European Parliament, the Council, the European Economic and Social Committee, the Committee of the Regions and the European Investment Bank, A Framework Strategy for a Resilient Energy Union with a Forward-Looking Climate Change Policy, COM/2015/080 (2015) 2.

${ }^{32}$ Recast Renewables Directive (n 13) Article 2.16 (emphasis added).

33 ibid. 
and discarded during the Directive's drafting process. ${ }^{34}$ No criterion for effective community control was ultimately enshrined in the Directive, which merely specifies how, for private undertakings, participation in community projects should not constitute their primary commercial or professional activity. ${ }^{35}$

This notion of renewable energy community is distinct from that of 'selfconsumer', which is defined by the recast Directive as:

\begin{abstract}
a final customer operating within its premises located within confined boundaries or, where permitted by a Member State, within other premises, who generates renewable electricity for its own consumption, and who may store or sell self-generated renewable electricity, provided that, for nonhousehold renewable self-consumers, those activities do not constitute their primary commercial or professional activity. ${ }^{36}$
\end{abstract}

The notion of self-consumer, too, encompasses diverse scenarios, such as, for example, residents fitting solar panels on their roof, or a farmer installing a windmill to cater for the energy needs of his/her farm. The recast Renewables Directive specifically contemplates also the possibility that self-consumers act in groups ${ }^{37}$ and that their installations be managed by third parties, which are not to be regarded as renewable self-consumers themselves. ${ }^{38}$

The distinguishing features of the notion of renewable energy community visà-vis that of self-consumer in the Directive are the type of agency involved, and the purpose and size of projects. With regard to agency, the notion of self-consumer does not necessarily entail collective action, but that of energy community does. As far as size is concerned, the recast Directive allows Member States to restrict preferential treatment only to self-consumers producing renewable energy below a certain threshold, ${ }^{39}$ whereas no such limitation is provided for community energy. This in turn suggests that community energy projects may generate larger amounts of energy and entail a greater degree of professionalisation. Finally, while the main objective of self-consumers is to produce energy for themselves and to sell only the excess to the grid, community energy projects are expected to provide 'environmental, economic or

\footnotetext{
${ }^{34}$ See the criteria listed in EU Commission, Proposal for a Directive on the promotion of the use of energy from renewable sources, COM/2016/767 (2016), Article 22.

${ }^{35}$ Recast Renewables Directive (n 13) Article 22.1.

${ }^{36}$ ibid., Article 2.14.

37 ibid., Article 2.15.

38 ibid., Article 21.1.5.

${ }^{39}$ ibid., Article 21.3.c sets the threshold at $30 \mathrm{~kW}$ of total installed capacity.
} 
social community benefits for its members or the local areas where it operates, rather than financial profits'. ${ }^{40}$

The recast Renewables Directive requires Member States to adopt 'enabling frameworks to promote and facilitate' both renewable energy communities and renewable self-consumption, by removing unjustified regulatory and administrative barriers. ${ }^{41}$ The main elements of these enabling frameworks and the related implementation measures will have to be reported in updates of Member States' integrated national energy and climate plans and progress reports. ${ }^{42}$

Thus, Member States are expected to enable consumers to generate renewable energy for their own consumption, free from discriminatory or disproportionate procedures and any charge or fee..$^{43}$ In relation to the electricity they consume from or feed into the grid, self-consumers should be able to generate, store and sell their excess production, without being subject to discriminatory or disproportionate procedures and charges and to network charges that are not cost-reflective. ${ }^{44}$ Equally, Member States are asked to enable communities to produce, consume, store and sell renewable energy without being subject to unjustified or discriminatory conditions or procedures. $^{45}$

The recast Renewables Directive does not attempt to solve all the intricate regulatory questions associated with facilitating the uptake of community energy, which are left to Member States to address. The Directive does, however, point to a set of factors - such as capacity-building, access to information, finance and markets - that have been crucial in the practice of those Member States with greater regulatory experience with the mainstreaming of community energy. The picture emerging from these pioneer Member States is multifaceted. The historically important role of the community sector in Denmark's energy transition has been widely reported in the literature, ${ }^{46}$ but has faltered in recent years. ${ }^{47}$ Germany's more recent and rather

${ }^{40}$ ibid., Article 2.15.

${ }^{41}$ ibid., Articles 21.6 and 22.4 .

${ }^{42}$ ibid., Articles 21.6 and 22.5.

${ }^{43}$ ibid., Article 21.2.a.ii.

${ }^{44}$ ibid., Article 21.2.a.i.

${ }^{45}$ ibid., Article 22.1.

${ }^{46}$ See for example Birgitte Egelund Olsen, 'Wind Energy and Local Acceptance: How to Get Beyond the NIMBY Effect' (2010) 19 EEELR 239; Sovacool (n 11) 836; ClientEarth (n 16$) 36$.

${ }^{47}$ See for example Mey and Diesendorf (n 18) and Thomas Bauwens, Boris Gotchev and Lars Holstenkamp, 'What Drives the Development of Community Energy in Europe? The Case of Wind Power Cooperatives' (2016) 13 Energy Research \& Social Science 136, 140-141. 
transformative experience with community energy - which presently delivers roughly $20 \%$ of the renewable energy in the country ${ }^{48}$ - has raised serious concerns over costs and economic viability. ${ }^{49}$ The UK's experience is much more recent and modest, ${ }^{50}$ but has clearly revealed the specific challenges associated with lack of institutionalised support and with the reform of energy subsidies for community energy. ${ }^{51}$ The next section takes a closer look at the experience of these pioneer EU Member States in order to unpack the main regulatory questions facing law-makers and policy-makers in the implementation of the recast Renewables Directive.

\section{Unpacking the Regulatory Questions}

Moving community projects beyond the grassroots level requires their mainstreaming into the energy system. This transformation in turn postulates the adoption of measures to define the scope of community energy, and to engender communities' capacity to engage in the development and operation of renewable energy generation plants, including through access to finance, technologies and infrastructure, such as the electricity grid. Furthermore, even though community projects are expected to counter so-called 'Not In My Back Yard' (NIMBY) reactions associated with the development of renewable energy generation plants, ${ }^{52}$ they also raise questions concerning who can participate in decision-making and how, who benefits from projects, and how the burdens are shared. This section considers these questions in

${ }^{48}$ Leuphana University 'Definition und Marktanalyse von Bürgerenergie in Deutschland' (Leuphana University

<https://digital.zlb.de/viewer/rest/image/15716863/definition_und_marktanalyse_von_buergerenergie_ in_deutschland_akt_2.pdf/full/max/0/definition_und_marktanalyse_von_buergerenergie_in_deutschlan d_akt_2.pdf> accessed 3 January 2019.

${ }^{49}$ See Geels and others (n 16) 905-906.

${ }^{50}$ See for example Gillian Bristow, Richard Cowell and Max Munday, 'Windfalls for Whom? The Evolving Notion of "Community" in Community Benefit Provisions from Wind Farms' (2012) 43 Geoforum 1108.

51 See REN21, 'Renewables 2018 Global Status Report' (REN21 2018) 41 http://www.ren21.net/wp-content/uploads/2018/06/17-8652_GSR2018_FullReport_web_final_.pdf accessed 25 January 2019 and Community Energy England, 'State of the Sector Report 2018' (Community Energy England 2018) 29 <https://communityenergyengland.org/pages/state-of-thesector-report-2018/> accessed 4 December 2018.

52 See for example Patrick Devine-Wright, 'Beyond NIMBYism: Towards an Integrated Framework for Understanding Public Perceptions of Wind Energy' (2005) 8 Wind Energy 125; Olsen (n 46); Patrick Devine-Wright, Renewable Energy and the Public: From NIMBY to Participation (Routledge 2014). 
turn, looking at the regulatory answers provided in the recast Renewables Directive, and in the practice of pioneer Member States.

\subsection{Who Is the Community?}

Much literature investigates the involvement of local residents and stakeholders in decision-making on the generation of renewable energy, ${ }^{53}$ drawing a distinction between deliberative participation, as opposed to mere strategies to engender social acceptance of the development of renewable energy generation plants. ${ }^{54}$ To the knowledge of the author, however, no legal scholarship has so far looked at the specific criteria that are used to define the scope of community membership in law and policy. ${ }^{55}$

In this regard, social scientists often distinguish between communities 'of place' - indicating those who happen to live in the area where a project is developed and communities 'of interest' - indicating those who choose to actively engage with a project, regardless of where they live. ${ }^{56}$ Reportedly, both typologies of community engage in the generation of renewable energy in practice. ${ }^{57}$

As seen above, the recast Renewables Directive lays down a set of criteria to identify renewable energy communities, largely focusing on communities of place. Firstly, the Directive requires that participation in projects be open and voluntary, autonomous, and effectively controlled by shareholders or members that are located in the proximity of the renewable energy projects owned and developed by that community. ${ }^{58}$ This requirement clearly prioritises those that live on or near a project

${ }^{53}$ See for example Mhairi Aitken, Seonaidh McDonald and Peter Strachan, 'Locating "Power" in Wind Power Planning Processes: The (Not so) Influential Role of Local Objectors' (2008) 51 Jof Environmental Planning and Management 777; Maria Lee and others, 'Public Participation and Climate Change Infrastructure' (2013) 25 JEL 33; Maria Lee, 'Knowledge and Landscape in Wind Energy Planning' (2017) 37 LS 3.

${ }^{54}$ See Chiara Armeni, 'Participation in Environmental Decision-Making: Reflecting on Planning and Community Benefits for Major Wind Farms' (2016) 28 JEL 415.

${ }^{55}$ For reflections from other social sciences, see Neil Simcock, 'Exploring How Stakeholders in Two Community Wind Projects Use a "Those Affected" Principle to Evaluate the Fairness of Each Project's Spatial Boundary' (2014) 19 Local Environment 241; Ben Campbell, Jon Cloke and Ed Brown, 'Communities of Energy' (2016) 3 Economic Anthropology 133.

56 The elaboration of these notions is attributed to the classic works by Harold F Kaufmann, 'Towards an Interactional Concept of Community' (1959) 38 Social Forces 8. See for example Mark Brennan, Jeffrey Birdger and Theodore R Alter, Theory, Practice, and Community Development (Routledge 2013) 41.

${ }^{57}$ See for example Bristow, Conwall and Munday (n 50).

${ }^{58}$ Recast Renewables Directive (n 13) Article 2.16.a. 
site, vis-à-vis those that may have an interest in getting involved. However, no definition of proximity is provided in the recast Renewables Directive, which leaves it to Member States to identify the relevant criteria. The notion of community in the Directive is also rather open-ended, and encompasses subjects other than natural persons, such as local authorities, municipalities, and SMEs. ${ }^{59}$ The Directive makes some reference to equity considerations, asking that participation in community energy projects be accessible to 'all consumers, including those in low-income or vulnerable households' ${ }^{60}$

The experience of pioneer Member States shows that law and policy contribute to determine the scope of community membership in various ways. When a community initiates a project, it is, in principle, free to define the boundaries of community membership, in the context of a process of self-identification. ${ }^{61}$ Thus, a community initiating a renewable energy generation project may decide, for example, to restrict membership to those residing on an island, or in a housing estate. In practice, the way a community self-defines is conditioned by eligibility criteria embedded in law and policy. ${ }^{62}$ For instance, if public funding to develop community energy projects is made available only to certain groups (e.g. rural communities), this would clearly condition the type of community projects that are likely to emerge. Similarly, the choice of legal form to shape community endeavours - most typically, cooperatives, trusts, foundations or community owned companies ${ }^{63}-$ is in principle left to communities' discretion. Nevertheless, criteria concerning eligibility to access support or other incentives may condition a community's choice of legal form. For example, the cooperative model has historically been predominant in Denmark, ${ }^{64}$ and is presently widespread in Germany ${ }^{65}$ but not as frequent in the UK. ${ }^{66}$

${ }^{59}$ Ibid., Article 2.16.b.

${ }^{60}$ Ibid., Article 22.4.f.

${ }^{61}$ For example, the Community Empowerment (Scotland) Act, Part 1, 1.11 defines community as including 'any community based on common interest, identity or geography'.

${ }^{62}$ As suggested also in Barry Barton and Michael Goldsmith, 'Community and Sharing' in Lila Barrera-Hernandez and others (eds), Sharing the Costs and Benefits of Energy and Resource Activity: Legal Change and Impact on Communities (OUP 2016) 31-32.

${ }^{63}$ See for example Claire Haggett and Mhairi Aitken, 'Grassroots Energy Innovations: The Role of Community Ownership and Investment' (2015) 2 Current Sustainable/Renewable Energy Reports 98, 101; ClientEarth (n 16) 21-22. See also Scottish Government, Onshore Policy Statement (2017) 27.

${ }^{64}$ See for example Bauwens, Gotchev and Holstenkamp (n 47) 140-141.

${ }^{65}$ See for example Eva Schmid and others, 'Imagine All These Futures: On Heterogeneous Preferences and Mental Models in the German Energy Transition' (2017) Complete Energy Research \& Social Science 45, 45; Diana Süsser, Martin Döring and Beate Ratter, 'Harvesting Energy: Place and 
Law and policy have an even more prominent role in determining the scope of community membership in relation to shared ownership. Danish law, for example, includes a specific definition of proximity, requesting wind farm developers to offer a 20 percent ownership stake to those living at a distance of $4.5 \mathrm{~km}$ from the project site. ${ }^{67}$ If the shares are not sold, they may be offered to other local residents. This right only benefits individuals. ${ }^{68}$ The fact that shares are offered for sale further delimits the scope of eligible community members only to those with the financial means to make a purchase. ${ }^{69}$ Availability of financial capital therefore crucially determines who becomes involved in a shared ownership project.

This approach to shared ownership has reportedly failed to revitalise community support for renewable energy generation in Denmark. ${ }^{70}$ Indeed, whether or not this kind of shared ownership would qualify as community energy in the context of the recast Renewables Directive may be questioned. As seen above, the Directive requests that projects are 'effectively controlled by shareholders or members that are located in the proximity of the renewable energy projects owned and developed by that community' ${ }^{71}$ Low threshold of local ownership such as that required under Danish law may therefore not be enough for projects to be eligible for the treatment reserved to renewable energy communities by the recast Renewables Directive. The Directive's reference to 'applicable national law', however, seems to leave much room for manoeuvre to national law-makers in this regard. ${ }^{72}$

The approach embedded in Danish law has inspired similar measures in the UK, where a 'community electricity right' was introduced in 2015. This right gives 'individuals resident in a community or groups connected with a community, or both' (sic), the right to buy a stake in new commercial renewable projects that are either located in the community (in case of land-based projects), or adjacent to the

Local Entrepreneurship in Community-Based Renewable Energy Transition' (2017) 101 Energy Policy 332.

${ }^{66}$ See for example Gill Seyfang and others, 'A Grassroots Sustainable Energy Niche? Reflections on Community Energy in the UK' (2014) 13 Environmental Innovation and Societal Transitions 21.

${ }^{67}$ Promotion of Renewable Energy Act (Denmark) Act no. 1392 of 27 December 2008, sections $13-17$.

${ }^{68}$ As noted also in Rønne (n 17) 185.

${ }^{69}$ ibid, 186.

47) $140-141$

${ }^{70}$ See the analysis in Mey and Diesendorf (n 18); and Bauwens, Gotchev and Holstenkamp (n

${ }^{71}$ Recast Renewables Directive (n 13) Article 2.16.a.

72 ibid. 
community (in case of offshore projects). ${ }^{73}$ The UK has opted for a voluntary approach, and regulatory powers will be exercised only if the voluntary approach does not deliver the hoped for results. ${ }^{74}$ The factors that may be used for identifying the beneficiaries of the community energy right include distance from the facility, the number of residents, and administrative boundaries. ${ }^{75}$ Furthermore, due to high levels of energy poverty in the UK, approaches to enable poorer segments of the population to engage with community energy through the establishment social enterprises have been experimented with in Scotland, with alternate fortunes. ${ }^{76}$

Even though there are marked differences between the approaches to the definition of community membership in the UK and Denmark, a geographical criterion has prevailed in both. This focus on communities of place is associated with a desire to deliver social acceptance and counter local resistance to the development of projects, and chimes with the approach adopted in the recast Renewables Directive. Communities of place are in principle better equipped to access the natural resources needed to generate some forms of renewable energy, such as water (in the case of hydro) or land (in the case of wind). When a community does not have access to these already, however, the issue is whether and how law and policy facilitate access to these resources. In Denmark, for example, expropriations for the establishment of wind farms must simply comply with general planning law requirements. ${ }^{77}$

Scotland has taken a rather original approach to this matter, by adopting a policy target for community ownership, ${ }^{78}$ coupled with a right to buy land, even in cases where the land owner is unwilling to sell. ${ }^{79}$ The Community Empowerment (Scotland) Act 2015 introduced communities' right to acquire land 'wholly or mainly

${ }^{73}$ Infrastructure Act (2015), paras 38-39. The parallel with Danish law is highlighted also in McHarg (n 17) 302.

${ }^{74}$ DECC, Infrastructure Bill: The Community Electricity Right Policy Brief (2014).

${ }^{75}$ Infrastructure Act (2015), schedule 6.

${ }^{76}$ One example of such endeavours was Our Power, which operated between 2015 and 2019, before running into difficulties and ceasing to trade in January 2019: https://our-power.co.uk/about accessed 2 February 2019.

${ }^{77}$ See for example Planning Act (Denmark), Consolidated Act No. 813 of 21 June 2007. sections 47-50. See the analysis in Danish Nature Agency: Naturstyrelsen (2015) available at http://naturstyrelsen.dk/media/131731/vejledning_06012015_web.pdf accessed 25 January 2019, 19.

${ }^{78}$ Scottish Government, Electricity Generation Policy Statement (2013); and the targets in Scottish Government, Scottish Energy Strategy (2017) 42, which maintains: 'Our ambition remains to ensure that, by 2020, at least half of newly consented renewable energy projects will have an element of shared ownership.'

${ }^{79}$ See McHarg (n 17) 307-310; Malcolm Combe, 'The Environmental Implications of Redistributive Land Reform' (2016) 18 Environmental L Rev104. 
abandoned or neglected' or somehow managed in a way that was detrimental to a community's 'environmental wellbeing' ${ }^{80}$ In addition, the Land Reform (Scotland) Act 2016 introduced a community right to buy land to further sustainable development, which became operational in July 2018. ${ }^{81}$ These seemingly radical steps were taken in the context of a pattern of land-ownership that, for historical reasons, was reportedly one of the most concentrated in the world.$^{82}$ So far, no evidence exists that this new right has been used to initiate community energy projects. In fact, community land acquisitions may well end up favouring other land uses, such as the establishment of protected areas, with the aim of preventing renewable energy developments.

The case of Scotland also suggests that there may be entrenched barriers to communities' full project ownership. The Scottish Government had initially introduced policy targets for full community ownership, ${ }^{83}$ but the 2017 Energy Strategy favours shared ownership. ${ }^{84}$ Yet, evidence from Denmark suggests that shared ownership arrangements only propel community energy to a rather limited extent. $^{85}$

Finally, the focus on community of place in existing laws and policies raises the question of whether and how communities of interest should be better accommodated in policies and laws concerning community energy. At least in principle, project shares could be offered to all those willing to engage, rather than just local residents. Experience with equity-based crowdfunding - i.e. with investors purchasing an equity stake in the form of securities in a project or a commercial company $^{86}$ - suggests that there may be considerable financial opportunities to be seized by expanding the boundaries of project ownership beyond the local level. Unconventional sources of finance from willing citizens have reportedly played an increasingly prominent role in supporting community energy, especially in contexts

${ }^{80}$ Community Empowerment (Scotland) Act (2015) s 74

${ }^{81}$ Land Reform (Scotland) Act (2016) Part 5.

${ }^{82}$ Annie McKee and others, 'The Scottish Private Estate' in Jayne Glass and others (eds) Lairds, Lands and Sustainability (Edinburgh UP 2013) 62, 65, as cited by Combe (n 79) fn. 38. See also McHarg (n 17) 306.

${ }^{83}$ Scottish Government, Community Energy Policy Statement (2015) 7.

${ }^{84}$ Scottish Government, Scottish Energy Strategy (2017) 63.

${ }^{85}$ Mey and Diesendorf (n 18) 115 and Bauwens, Gotchev and Holstenkamp (n 47) 41.

${ }^{86}$ See Catherine Banet, 'Enabling the Crowdfunding of Energy Projects' in Lila BarreraHernandez and others (eds), Sharing the Costs and Benefits of Energy and Resource Activity: Legal Change and Impact on Communities (OUP 2016) 321. 
where public finance is scarce. ${ }^{87}$ And while pioneer countries have resorted to geographical criteria to determine the scope of community membership, a more flexible approach to the definition of community has already started to emerge, with nuancing between 'host' and 'less immediate' communities, in relation, for example, to off-shore renewable energy.$^{88}$

The implementation of the recast Renewables Directive therefore calls for more reflection on how law and policy define community membership and ownership, in order to better understand what are the more promising avenues to spur community action. The best opportunities for citizen-driven renewable energy generation may well reside in likeminded actors that do not necessarily live next to one another - as the case of solar cooperatives mushrooming all over pioneer Member States well demonstrates ${ }^{89}$ - rather than in communities living in the proximity of renewable energy projects as envisioned by the recast Renewables Directive.

\subsection{Building Communities' Capacity}

The literature often portrays community projects as a means to broaden access to energy within society, ${ }^{90}$ as well as to address justice questions associated with the energy transition. ${ }^{91}$ Yet, in and of themselves, these projects raise specific questions on how to engender communities' capacity to engage in the development and operation of renewable energy plants. For example, full project ownership often requires communities to collaborate, or even take the lead, in the establishment and/or management of renewable energy generation plants. ${ }^{92}$ This in turn presupposes a set of capabilities that can either already be embedded in a community, or be engendered by means of external support.

The recast Renewables Directive explicitly requires that regulatory and capacity-building support is provided to public authorities to enable and set up renewable energy communities, and to help such authorities to participate directly in community projects..$^{93}$ This requirement has clear implications for energy governance

\footnotetext{
${ }^{87}$ See ibid., 324; and DECC, Community Energy Strategy Update (2015) 22.

${ }^{88}$ See Bristow, Cowell and Munday (n 50); Barton and Goldsmith (n 62) 40.

${ }^{89}$ See for example https://www.edinburghsolar.coop/ last accessed 27 December 2018.

${ }^{90}$ See for example Saunders, Gross and Wade (n 8).

${ }^{91}$ See for example Jenkins and others (n 9) 177.

92 This issue is raised for example in Oteman, Wiering and Helderman (n 16).

${ }^{93}$ Recast Renewables Directive (n 13) Article 22.4.h.
} 
at the national and subnational levels, and may pave the way to new forms of EU scrutiny over the allocation and exercise of administrative powers within Member States.

Pioneer countries present significant differences concerning institutional support for community action. In Denmark the diffusion of community energy during the so-called oil-crisis and 'energy austerity' in the '70s was largely driven by farmers cooperatives and by the extensive powers of local authorities in matters of planning and the supply of public services, including energy. ${ }^{94}$ Similarly, the literature commonly attributes the recent flourishing of community energy in Germany to local entrepreneurship and to the leadership of technical and political pioneers, ${ }^{95}$ coupled with the exercise of the extensive powers of local authorities ${ }^{96}$ and the networking of community actors. ${ }^{97}$

Conversely, the UK presented a less favourable institutional landscape in support of community action. Due to local authorities' limited powers on energy governance, and the limited diffusion of the cooperative model, the recent adoption of community energy policies in England, Wales and Scotland was accompanied by the establishment of intermediaries supporting communities in their interactions with both authorities and corporate actors. The literature describes intermediaries as organisations 'connecting local projects with one another' as well as 'with the wider world', and thus helping to generate a 'shared institutional infrastructure' and knowledge transfer to sustain projects. ${ }^{98}$ These intermediaries have reportedly appeared 'in waves', with a decisive acceleration in recent years, as a result of the adoption of renewable energy targets at the EU, national and subnational levels. ${ }^{99}$

The plethora of actors presently working with community energy in the UK includes intermediaries established by national and subnational governments, as well

\footnotetext{
${ }^{94}$ Sovacool (n 11) 830.

${ }_{95}$ As suggested for example in Jürgen Hauber and Chantal Ruppert-Winkel, 'Moving towards Energy Self-Sufficiency Based on Renewables: Comparative Case Studies on the Emergence of Regional Processes of Socio-Technical Change in Germany' (2012) 4 Sustainability 491; Süsser,

${ }^{96}$ Stephen Hall, Timothy Foxon and Ronan Bolton, 'Financing the Civic Energy Sector: How Financial Institutions Affect Ownership Models in Germany and the United Kingdom' (2016) 12 Energy Research \& Social Science 5, 9.

${ }^{97}$ Süsser, Döring and Ratter (n 66) 332.

${ }^{98}$ See Tom Hargreaves and others, 'Grassroots Innovations in Community Energy: The Role of Intermediaries in Niche Development' (2013) 23 Global Environmental Change 868, 870.

99 ibid, 870 and 872.
} Döring and Ratter (n 66). 
as non-governmental organisations and private sector professionals. ${ }^{100}$ Far from being mere neutral brokers providing a shared institutional infrastructure and enabling knowledge transfer, intermediaries have increasingly become 'framers and coordinators' of community action, ${ }^{101}$ professional services providers and even project partners. This phenomenon became particularly evident after the recent reform of UK renewable energy subsidies, which turned some intermediaries into project co-owners and shareholders, in order to ensure the continued viability of community projects. ${ }^{102}$ Rather problematically, no safeguards presently exist in the UK to ensure that these intermediaries do not take advantage of their position in relations with communities.

Therefore, while intermediaries in the UK have been crucial builders of communities' capacity to engage in renewable energy generation, the implementation of the recast Renewables Directive calls for a better understanding of the advantages and disadvantages of involving professional brokers, and of whether these ought to be regulated, and how, in order to address conflicts of interest that may arise in the performance of capacity-building and support activities. More generally, the Directive raises questions over the factors that successfully support community action and on what can be done in states where local authorities' powers on energy matters are limited.

\subsection{Access to Finance and Markets}

The mainstreaming of community energy greatly depends on the long-term sustainability of community energy projects. If projects are short-lived and end in disappointment, it is clearly hard to persuade other communities to become involved. The most existential question concerning the development of community projects is therefore that of access to financial resources, both to develop renewable energy generation plants, as well as to secure their upkeep and viability over time.

Different community ownership patterns have different financial implications. With shared ownership, access to finance may be necessary to enable whole communities, or individual community members, to become involved in projects

100 ibid.

101 ibid, 876.

102 As discussed in Andy Lyle (Locogen), Shared Ownership Lessons. Presentation delivered at the 2017 edition of the Scottish Government's Community and Renewable Energy Scheme Conference, Stirling - notes on file with the author. 
initiated and managed by others. With full community ownership, instead, the issue is rather to secure funds to initiate renewable energy projects. Literature from the social sciences has dedicated much attention to this topic, comparing different models and forms of support. ${ }^{103}$

Law and policy undoubtedly have a role to play in enabling community access to finance. In this connection, the recast Renewables Directive sketches out the core elements of a level playing field, requesting that Member States facilitate communities' access to finance and information; 104 and take into account 'specificities' of renewable energy communities in order to allow them to compete for support on an 'equal footing' with other market participants when designing 'measures that promote the use of renewable energy'. ${ }^{105}$ The Directive defines the latter as measures reducing the cost of energy, increasing the price at which it can be sold, or increasing the volume of such energy purchased, including through: investment aid, tax exemptions or reductions, tax refunds, renewable energy obligation support schemes, and direct price support schemes, including feed-in tariffs and sliding or fixed premium payments. ${ }^{106}$ These measures are expected to be implemented without prejudice to state aid rules under Articles 107 and 108 of the Treaty on the Functioning of the European Union (TFEU). ${ }^{107}$

The Directive's requirement that renewable energy communities compete for support on an equal footing with other market participants may not be compatible with the dedicated start up finance for the development of community projects, which is common practice in all pioneer countries. For example, in Denmark a fund established by law and replenished by way of energy taxes supports preliminary investigations by local wind turbine owners associations. ${ }^{108}$ Similarly, the Scottish Government's Community and Renewable Energy Scheme provides funds to help communities start renewable energy projects and fund pre-planning costs. ${ }^{109}$

\footnotetext{
${ }^{103}$ See for example Geels and others (n 16); Hall, Foxon and Bolton (n 96).

${ }^{104}$ Recast Renewables Directive (n 13) Article 22.4.g.

105 ibid, Article 22.7.

106 ibid, Article 2.5.

107 ibid, Article 22.7.

108 Promotion of Renewable Energy Act (n 67), Part 2, 21. See the analysis in Helle Tegner Anker and Marie Leer Jørgensen, 'Mapping of the Legal Framework for Siting of Wind Turbines' (2015) (Department of Food and Resource Economics, University of Copenhagen) IFRO Report 239

${ }^{109}$ See: <www.localenergyscotland.org> accessed 2 February 2019.
} $28-30$. 
Cooperative lending in Germany - partially funded by the German Public Development Bank - has historically supported community action, sponsoring the acquisition of renewable energy facilities by co-operatives, private householders and communities. ${ }^{110}$

The main means to secure finance to ensure the long-term viability of community projects, however, is the ability to sell community-produced renewable energy on the market. The recast Renewables Directive explicitly requires Member States to enable communities to access to 'all suitable' energy markets, with nondiscriminatory treatment when compared with other market participants. ${ }^{111}$

The practice of pioneer states is uneven in this regard. In Germany, community projects are subjected to special auctioning rules, vis-à-vis projects by commercial operators. ${ }^{12}$ Evidence from Denmark and the UK, conversely, indicates that the creation of a level playing field between energy producers has historically favoured commercial operators with large development portfolios. ${ }^{113}$

The challenges associated with building a level playing field have become manifest with recent feed-in tariff reforms. Feed-in tariffs have been introduced in several countries around the world to stimulate the diffusion of renewable energy technologies. ${ }^{114}$ The ways in which these tariffs are structured and reviewed over time, however, may have significant impacts on investors, and especially on community ones. ${ }^{115}$ And while feed-in tariffs are expected to be discontinued eventually, the timing of their phasing out is crucial. ${ }^{116}$

Community projects in the UK were hit particularly hard by recent renewable energy subsidy reforms, which have been linked to an increasing number of failed or stalled community projects. ${ }^{117}$ By comparison, in Germany and Denmark the sustained use of fixed feed-in tariffs has historically been crucial to the consolidation of

\footnotetext{
${ }^{110}$ As reported in Nolden (n 16) 548; Ronan Bolton, Timothy Foxon and Stephen Hall, 'Energy Transitions and Uncertainty: Creating Low Carbon Investment Opportunities in the UK Electricity Sector' [2016] Environment and Planning C: Government and Policy 1387, 12.

${ }^{111}$ Recast Renewables Directive (n 13) Article 22.7.

${ }^{112}$ Renewable Resources Act (2017) s36(g).

${ }^{113}$ See Bauwens, Gotchev and Holstenkamp (n 47) 146.

${ }^{114}$ Reportedly, 113 countries had feed-in tariffs in place in 2017: REN21 (n 51) 200.

115 Toby Couture and Yves Gagnon, 'An Analysis of Feed-in Tariff Remuneration Models: Implications for Renewable Energy Investment' (2010) 38 Energy Policy 955, 963.

${ }^{116}$ Recast Renewables Directive (n 13) recital, para 17.

117 As reported for example in Community Energy England (n 51) 27-28.
} 
community energy, providing confidence and certainty in investment returns. ${ }^{118}$ In Germany, nevertheless, the widespread uptake of renewable energy has engendered unexpected, perverse outcomes for the cost of electricity, placing financial burdens on lower income households, and benefitting upper income ones. ${ }^{119}$ Measures to address this inefficiency have recently been put in place, resulting in a slowdown in the uptake of community energy. ${ }^{120}$

As the recent landslide of litigation associated with reforms in some EU Member States eloquently illustrates, setting the right level of renewable energy subsidies is not easy, ${ }^{121}$ and not only in relation to community projects. ${ }^{122}$ The implementation of the recast Renewables Directive, however, will bring in an additional layer of complexity, requesting Member States to factor in the specificities of community energy when reforming renewable support schemes. ${ }^{123}$

A related vexed question is that of access to the electricity grid. Even though new ways of transmitting electricity are being explored, including through mini and smart grids, ${ }^{124}$ by and large community projects aiming to sell energy on the market need to be connected to the national/regional grid. In this regard, the recast Renewables Directive requires Member States to ensure that the relevant distribution system operator cooperates with renewable energy communities to facilitate energy transfers within communities, while at the same time, ensuring that renewable energy communities that supply energy provide aggregation or other commercial energy services 'are subject to the provisions relevant for such activities'. ${ }^{125}$ Renewable energy communities are expected to contribute in 'an adequate, fair and balanced way' to the overall cost sharing of the system 'in line with a transparent cost-benefit

\footnotetext{
${ }^{118}$ Hall, Foxon and Bolton (n 96) 8; Sovacool (n 11) 830; and Bauwens, Gotchev and Holstenkamp (n 47) 140.

${ }_{119}$ Peter Grösche and Carsten Schröder, 'On the Redistributive Effects of Germany's Feed-in Tariff' (2014) 46 Empirical Economics 1339.

120 REN21 (n 51) 41.

121 Geels and others (n 16) 906.

${ }^{122}$ See for example Daniel Behn and Ole Kristian Fauchald, 'Governments under Cross-Fire: Renewable Energy and International Economic Tribunals' (2015) 12 Manchester Journal of Intl Economic L 117; Fernando Dias Simões, 'Charanne and Construction Investments v. Spain: Legitimate Expectations and Investments in Renewable Energy' (2017) 26 RECIEL 174; Fernando Dias Simões, 'Blusun S.A. and Others v Italy: Legal (in)Stability and Renewable Energy Investments' (2017) 26 RECIEL 298.

${ }^{123}$ Recast Renewables Directive (n 13) Article 22.7.

${ }^{124}$ Matthew Lockwood, 'Creating Protective Space for Innovation in Electricity Distribution Networks in Great Britain: The Politics of Institutional Change' (2016) 18 Environmental Innovation and Societal Transitions 111.

${ }^{125}$ Recast Renewables Directive (n 13) Articles 22.4.c and 22.4.b.
} 
analysis of distributed energy sources' by the competent national authorities. ${ }^{126}$ It therefore seems clear that the Directive does not intend to stimulate the uptake of community energy whatever the cost. The matter of access to the grid, however, has proven to be particularly sensitive in pioneer states.

All pioneer countries provide some form of statutory access to the electricity grid for community energy. Yet in practice, connection costs have hindered the commercial viability of several projects. Again, the UK is a case in point, with communities required to bear grid connection costs, including a share of the costs of network reinforcement. ${ }^{127}$ As a result, the costs associated with grid access have been a significant obstacle for the development of projects in marginal areas with great renewable energy generation potential, like the Scottish islands. ${ }^{128}$ Conversely, in Denmark, connection costs are shared, and grid operators take charge of expansion and upgrade costs. ${ }^{129}$ In Germany, the expansion of community energy has engendered momentum for the re-municipalisation of electricity grids by local authorities. ${ }^{130}$ Admittedly, public ownership provides no guarantee of improved distributional and economic efficiency outcomes, ${ }^{131}$ but the establishment of a publicly-owned, not-for-profit energy company is presently under consideration in Scotland, with the objective, amongst others, to support local energy generation. ${ }^{132}$

More generally, questions of access to the energy grid underlie deeper interrogatives on how to reform existing energy governance and infrastructure arrangements in order to accommodate community energy. The implementation of the recast Renewables Directive therefore calls for greater reflection on how renewable energy subsidies and grid access can be best designed to mainstream and make community energy investments resilient and cost-effective in the long run.

126 ibid, Articles 22.4.i and 22.4.d.

${ }^{127}$ National Grid Electricity System Operator, Connection and Use of System Code (2014) section 2.14. See also Ofgem, Community Energy Grid Connections Working Group Report (2014) 2.

${ }^{128}$ UK House of Commons Scottish Affairs Committee, The Renewable Energy Sector in Scotland, (2016), 82-88.

${ }^{129}$ Electricity Supply Act (2017) para 67.

${ }^{130}$ Hall, Foxon and Bolton (n 96) 10. On re-municipalisation see Timothy Moss, Sören Becker and Matthias Naumann, 'Whose Energy Transition Is It, Anyway? Organisation and Ownership of the Energiewende in Villages, Cities and Regions' (2015) 20 Local Environment 1547, 1155.

${ }^{131}$ Burke and Stephens (n 7) 41.

${ }^{132}$ Scottish Government, Publicly Owned Energy Company: Strategic Outline Case (2018) ii. 


\subsection{Decision-making, Burden- and Benefit-sharing}

Even though community projects are expected to engender greater and better citizen involvement in decisions over renewable energy generation plants and a fairer distribution of the related burden and benefits, they also raise questions over who participates in decision-making, how and on what terms. Like any other development changing the status quo, in fact, community energy projects require that new equilibria be found between societal interests intersecting in a specific site. For example, depending on the technology deployed, those residing in the vicinity of a renewable energy generation plant may be exposed to noise and other forms of nuisance, and/or suffer a loss in the value of their real estate. In this regard, community energy projects posit questions that do not significantly differ from noncommunity owned ones, which concern the compensation of those negatively affected by the development and operation of a given plant, and the sharing of the benefits produced by it.

Evidence of community projects that have engendered a remarkable degree of opposition certainly exists. One eloquent example is the Viking Energy project in Shetland. A joint venture between the local community and a utility company, this large-scale, shared ownership community project was authorised in 2007 with the aim to set 103 wind turbines around Shetland, generating a potential output of up to 457 megawatts, one of the largest in the UK. Twelve years on, however, the project has attracted a flurry of public opposition and litigation - instigated on the basis of legislation concerning the protection of birds' habitats, ${ }^{133}$ and on the rights of local crofters $^{134}$ - and remains far from completion. Similarly, in England, planning law has been successfully used to argue that the donation to local residents of a proportion of the turnover from a community renewable energy development should not be the subject of a material consideration on the related planning application. ${ }^{135}$

The recast Renewables Directive does not say much on how to address challenges such as these. The Directive requires that Member States ensure that

133 This specific dispute is now concluded. See UK Supreme Court, Sustainable Shetland v The Scottish Ministers [2015] UKSC 4. See McHarg (n 17) 314.

${ }^{134}$ Decision of the Scottish Land Court, Viking Energy Wind Farm LLP (Applicant) v Crofters having rights in the Common Grazings of the Townships of Sandwick, Sweening \& Laxo and Other Common Grazings (Respondents), Case reference SLC 31/16, 5 September 2018

${ }^{135}$ Wright, R (on the application of) v Forest of Dean District Council Resilient Energy Serverndale Ltd [2017] EWCA Civ 2102 (14 December 2017). 
'unjustified regulatory and administrative barriers' are removed and that community projects are subject to 'fair, proportionate and transparent procedures', including on registration and licensing. ${ }^{136}$ The Directive does not provide much detail on the procedures to be adopted. Equally, the Directive expects community energy projects 'to provide environmental, economic or social community benefits for its members or the local areas where it operates rather than financial profits'. ${ }^{137}$ This requirement seemingly expects community projects to deliver more than just electricity and financial returns. Yet the Directive does not specify how such environmental, economic, or social benefits ought to be defined, measured or reported.

These matters are left to Member States to address, in the general frame set by EU law instruments on environmental impact assessment, ${ }^{138}$ public participation, ${ }^{139}$ access to justice and access to environmental information. ${ }^{140}$ These instruments are not specifically designed to deal with community energy. Rather, community energy projects are yet another type of activity falling within the scope of application of these instruments. In this connection, a fundamental distinction has to be drawn between intra-community relations - i.e. between those involved in a given project - and extracommunity relations - i.e. between those taking part in a community project and other local residents and stakeholders who are not involved in a given project.

As far as intra-community relations are concerned, projects in full community ownership may be expected to deliver a greater degree of community control, and to put community members at the centre of decision-making processes. In principle, therefore, community ownership should mean greater public acceptance and fewer complaints over the loss of amenity associated with the development and operation of a project. The issue is, however, to understand whether this assumption is well founded in practice.

${ }^{136}$ Recast Renewables Directive (n 13) Articles 22.4.a and 22.4.d.

137 ibid, Article 2.16.c.

${ }^{138}$ Directive 2011/92/EU on the assessment of the effects of certain public and private projects on the environment as amended by Directive 2014/52/EU of 16 April 2014 [2014] OJ L124/1.

${ }^{139}$ Directive 2003/35/EC of 26 May 2003 providing for public participation in respect of the drawing up of certain plans and programmes relating to the environment and amending with regard to public participation and access to justice Council Directives 85/337/EEC and 96/61/EC, [2003] OJ L156/17.

${ }^{140}$ Directive 2003/4/EC of 28 January 2003 on public access to environmental information and repealing Council Directive 90/313/EE, [2003] OJ L41/26. 
Very little literature exists on how energy communities make decisions, and what processes exist to ensure legitimacy and fairness in deliberative processes. ${ }^{141}$ The legal form of community endeavours may determine some aspects of communities' internal organisation. For example, legislation on cooperatives may require specific decision-making processes. Other aspects, nevertheless, are likely to be left entirely to communities' self-organisation. While this margin of discretion chimes with empowerment and self-governance narratives, ${ }^{142}$ it may also engender conflict and exclusion, starting from the point at which the scope of community is defined, and continuing into day-to-day decision-making. ${ }^{143}$

The matter of extra-community relations, conversely, is better regulated. Community projects are subjected to screening and approval, like any other development. These requirements vary from one legal system to the other, but planning law typically enables stakeholders (eg nature and heritage conservation organisations) and/or those affected (eg neighbouring estates) to object to developments in the context of the planning permission process. In future, planning law is expected to acquire an increasingly prominent role in the context of the decentralisation of energy production. ${ }^{144}$ Furthermore, depending on their size, community energy projects are likely to be subjected to an environmental impact assessment (EIA). ${ }^{145}$ EIAs are an important means for the public to have a say on whether or not a project ought to be carried out, its siting and design. In the EU a level playing field on this issue may be said to exist, at least in principle, due to the implementation of the EIA Directive. ${ }^{146}$ Before a project gets underway, therefore, EIAs and planning processes provide opportunities to debate burden-sharing, in the context of decisions over project siting. When a project has been approved, negative impacts may be mitigated by means of compensation, obtained through the exercise of tort or public law remedies.

Innovative solutions to deal with these kinds of challenges have been experimented with in Denmark, where a semi-automatic mechanism for the

${ }^{141}$ As noted also in Bregje van Veelen, 'Negotiating Energy Democracy in Practice: Governance Processes in Community Energy Projects' (2018) 27 Environmental Politics 644.

${ }^{142}$ Slee and Harnmeijer (n 11) 45.

${ }^{143}$ As noted in Aitken, McDonald and Strachan (n 54).

144 Tomain (n 12) 212.

${ }^{145}$ See for example Danish Planning Act, section 35, as discussed in Rønne (n 17) 179-180.

${ }^{146}$ Directive 2011/92/EU on the assessment of the effects of certain public and private projects on the environment (codification) [2011]OJ L26/1 as amended. 
compensation for the loss of value of real estate exists. In particular, Danish law requires those developing new wind energy generation plants to compensate those affected before a project is developed, and only if the loss is of a certain quantity. ${ }^{147}$ As Rønne notes, this arrangement conveys the impression that windfarms are a source of nuisance by default. ${ }^{148}$ Questions have been raised also over the adequacy of compensation provided - which only covers some impacts, such as loss of value, but not all loss of amenity - and over the fact that receiving compensation hinders subsequent legal action, even where the nuisance or loss of value are greater than estimated. ${ }^{149}$

Finally, EIA and planning law intertwine with the protection of human rights obligations enshrined in international, regional, or national law, requiring states to establish procedures enabling those affected to be informed and heard during the planning phase, to enjoy access to adequate remedies to address grievances, and to assess negative impacts on the enjoyment of human rights. State obligations in this connection have most recently been elucidated by the United Nations Special Rapporteur on the issue of human rights obligations relating to the enjoyment of a safe, clean, healthy and sustainable environment. ${ }^{150}$ While states generally enjoy a certain discretion in striking a balance between legitimate societal interests, that balance cannot be unreasonable or result in unjustified, foreseeable infringements of human rights. ${ }^{151}$ In assessing whether a balance is reasonable, relevant factors include whether the decision-making process satisfies the procedural obligations described above; whether its outcomes accord with national and international standards; whether they are not retrogressive and non-discriminatory. ${ }^{152}$ While differences in implementation clearly exist in practice, the 1998 Aarhus Convention ${ }^{153}$ has created a minimum set of core obligations across the EU on these matters. ${ }^{154}$ In practice, some $188-189$.

${ }^{147}$ Promotion of Renewable Energy Act (n 67), Part 2. See also the analysis in Rønne (n 17)

148 As suggested also in Rønne (n 17) 190.

${ }^{149}$ As noted for example in Jørgensen (n 17).

${ }^{150}$ Report of the Special Rapporteur on the issue of human rights obligations relating to the enjoyment of a safe, clean, healthy and sustainable environment, UN Doc A/HRC/37/59 (24 January 2018).

151 Ibid., 32-33.

152 Ibid., principles 7-11.

${ }^{153}$ See Aarhus Convention on Access to Information, Public Participation in Decision-making and Access to Justice in Environmental Matters 2161 UNTS 447 (1998), arts 5, 6 and 9.

${ }^{154}$ As noted for example in Marjan Peeters and Thomas Schomerus, 'Modifying Our Society with Law’ (2014) 4 Climate L 131, 303. 
human rights-based complaints against the development of renewable energy projects have already been made, both in the context of the European Convention of Human Rights $^{155}$ and of the Aarhus Convention. ${ }^{156}$

No systematic study of public opposition to and litigation over community energy projects has been carried out to date. ${ }^{157}$ The evidence is anecdotal and patchy. The impending implementation of the Renewables Directive therefore calls for greater analysis of the circumstances in which community projects attract public opposition, and why. This understanding would provide precious insights for policymakers looking at removing 'unjustified regulatory and administrative barriers' to community projects and at 'fair, proportionate and transparent procedures' to make them happen, as required by the Directive.

A similar scarcity of data exists in relation to benefit-sharing arrangements associated with community projects. Benefit-sharing arrangements are widespread practice in various natural resource management and extractive activities, both to mitigate the negative impacts of, and reduce opposition to, projects and increase their social acceptance. ${ }^{158}$ The contours of developers' obligations are context specific and depend on the applicable legal frameworks, as well as on industry practices. Communities living in the vicinity of a renewable energy generation project typically receive various economic and non-economic advantages from the developers, ${ }^{159}$ including for example monetary payments per capacity installed, ${ }^{160}$ as well as electricity at discounted prices or grants to support energy efficiency. Indeed, the practice of offering shares in projects developed by commercial operators - as in

155 See European Court of Human Rights, Fägerskiöld v Sweden, Application no. 37664/04 Admissibility; and European Court of Human Rights, Vecbaštika and Others v Latvia, Application no. 52499/11, Pending.

156 See for example Aarhus Convention Compliance Committee Communication ACCC/C/2012/68, where the UK was found not to be in compliance with Article 7 of the Aarhus Convention, because its National Renewable Energy Plan was not subjected to public participation.

${ }^{157}$ While the matter of litigation associated with the establishment of wind farms is well covered in the literature - on the UK see e.g. Elizabeth Fisher, 'Law and Energy Transitions: Wind Turbines and Planning Law in the UK' (2018) 38 Oxford Journal of Legal Studies 528 - to the knowledge of the author none of these studies has considered specifically litigation associated with community projects.

${ }^{158}$ See for example the analysis in Elisa Morgera, 'The Need for an International Legal Concept of Fair and Equitable Benefit Sharing' (2016) 27 EJIL 353.

${ }^{159}$ As explained for example in Rønne (n 17) 180; LeRoy C Paddock and Max Greenblum, 'Community Benefit Agreements for Wind Farm Siting in Context' in Lila Barrera-Hernandez and others (eds), Sharing the Costs and Benefits of Energy and Resource Activity: Legal Change and Impact on Communities (OUP2016).

${ }^{160}$ See for example Scottish Parliament Brief, Renewable Energy: Community Benefit and Ownership (2012) 13. 
Denmark - may in and of itself be viewed as a means to share economic benefits with local communities. ${ }^{161}$ Developers may furthermore offer communities non-monetary benefits, such as the development of common facilities for recreation, education, etc.

When a community, rather than a commercial operator, is in charge of a project, benefit-sharing arrangements assume both intra- and extra-community nuances. At the intra-community level, it is up to communities to choose how to govern their internal arrangements, though intermediaries can be important in steering community practice in this connection. At the extra-community level, the question of benefit-sharing re-surfaces in relation to those who are not part of a given project. This in turn translates into a set of questions on who benefits, how, and the criteria to identify benefits and beneficiaries.

No standard practice concerning benefit-sharing has emerged in pioneer states. The practice of so-called 'community protocols' - borrowed from other areas from natural resource management ${ }^{162}$ - has been used as a means to empower communities in relations with developers, as well as public authorities. Intermediaries have played an important role in the design of model protocol templates and, more generally, in engendering community capacity to negotiate benefits. ${ }^{163}$ Some law-makers have adopted voluntary guidelines on community benefits, ${ }^{164}$ whereas others have adopted a more institutionalised approach to benefit-sharing. ${ }^{165}$ There is, however, a great deal of variation amongst states, and even within the same state. For example, benefitsharing is not a formal requirement in the UK, ${ }^{166}$ even though it is expected in practice. ${ }^{167}$ Scotland has created a registry giving visibility to community benefits and adopted guidelines on what benefits should consist of, as well as how they should be determined, placing emphasis on dialogue with communities, but leaving it to developers to identify who these may be. ${ }^{168}$

In spite of their widespread uptake, the literature reports how benefit-sharing

${ }^{161}$ McHarg (n 17) 301-302.

162 See for example Harry Jonas, Kabir Bavikatte and Holly Shrumm, 'Community Protocols and Access and Benefit-Sharing' (2010) 12 Asian Biotechnology and Development Review 49.

${ }^{163}$ As reported for example in Bristow, Cowell and Munday (n 50) 1115.

${ }^{164}$ See for example Scottish Government, Good Practice Principles for Community Benefits from Onshore Renewable Developments (2015).

${ }^{165}$ For Denmark, see Promotion of Renewable Energy Act (n 67), ss 13-17.

${ }^{166}$ See DECC, Benefits Best Practice Guidance (2014).

${ }^{167}$ As noted in McHarg (n 17) 306.

${ }^{168}$ See Scottish Government, Good Practice Principles for Community Benefits from Onshore Renewable Developments (2013) 6-7. 
arrangements still tend to be perceived as a bribe to secure project approval and/or minimise public resistance. ${ }^{169}$ Some authors point to the advantages of greater benefits institutionalisation associated with shared project ownership ${ }^{170}$ and of spelling out benefits in more positive terms. ${ }^{171}$ Increasing opposition to the development of wind farms in Denmark, however, does not necessarily corroborate this proposition. ${ }^{172}$

More generally, the literature points out how, while policy-making in pioneer countries has relied on the assumption that communities of place tend to privilege long-term, collective benefits, this assumption is not necessarily justified in practice. ${ }^{173}$ Little systematic information exists on benefit-sharing arrangements associated with community projects. Since the recast Renewables Directive stipulates that community energy projects deliver benefits to the communities involved, as well as those affected, greater and deeper scholarly enquiry is needed to shed light on what may be regarded as best practices to ensure that community projects deliver the benefits they are expected to produce.

\section{An Agenda for Future Research}

The implementation of the recast Renewables Directive is expected to turn communities across the EU into prominent actors in the energy transition and to deliver more decentralised and polycentric energy governance. Law and policy have an important role to play in this transformation, by addressing the complex, layered, regulatory questions associated with turning community projects from grassroots into mainstream.

This article has mapped the main regulatory questions underlying the implementation of the Directive's provisions concerning community energy,

${ }^{169}$ See for example Noel Cass, Gordon Walker and Patrick Devine-Wright, 'Good Neighbours, Public Relations and Bribes: The Politics and Perceptions of Community Benefit Provision in Renewable Energy Development in the UK' (2010) $12 \mathrm{~J}$ of Environmental Policy \& Planning 255; Benjamin Walker, Duncan Russel and Tim Kurz, 'Community Benefits or Community Bribes? An Experimental Analysis of Strategies for Managing Community Perceptions of Bribery Surrounding the Siting of Renewable Energy Projects' (2017) 49 Environment and Behavior 59.

${ }^{170}$ See for example Walker, Russel and Kurz (n 165) 78.

${ }^{171}$ See for example David Rudolph, Claire Haggett and Mhairi Aitken, 'Community Benefits from Offshore Renewables: The Relationship between Different Understandings of Impact, Community, and Benefit' (2017) Environment and Planning C: Politics and Space 10.

${ }^{172}$ See Bauwens, Gotchev and Holstenkamp (n 47) 140-141; and Mey and Diesendorf (n 18).

${ }^{173}$ See Bristow, Cowell and Munday (n 50) 1108; Bregje van Veelen and Claire Haggett, 'Uncommon Ground: The Role of Different Place Attachments in Explaining Community Renewable Energy Projects' (2016) Sociologia Ruralis 1. 
providing insights into the way in which they have been addressed in pioneer EU Member States. While the answers to these regulatory questions will vary, depending on the political, economic and social characteristics of different locations, the preliminary investigation carried out in this paper has identified a set of clear knowledge gaps.

First, the implementation of the recast Renewables Directive calls for more analysis of how law and policy define community membership and ownership in different contexts. This analysis is necessary to understand what kind of community community of place vis-à-vis community of interest - and ownership patterns shared vis-à-vis full ownership - ought to be favoured and, ultimately, what meaning to attach to the notion of effective community control enshrined in the Directive.

Second, there is a need for greater study of measures that successfully support and build communities' capacity to engage in renewable energy generation, including the regulation of intermediaries, and of what can be done in states where local authorities' powers on these matters are limited.

Third, there is a need to urgently address the question of how to best reform existing energy governance and infrastructure arrangements in order to accommodate community energy, especially in relation to subsidies and access to the electricity grid. It is crucial to identify the regulatory conditions that make community energy viable in the long run, the conditions that make projects fail, and lessons that may be learnt from such failures.

Fourth, greater and better knowledge of when community projects attract public opposition would provide precious insights into how to remove regulatory and administrative barriers to, and create fair, proportionate and transparent procedures for community projects, as required by the Directive.

Finally, since the recast Renewables Directive stipulates that community energy projects deliver benefits to the communities involved, greater and better knowledge is required to shed light on practices that ensure that community projects actually produce benefits.

The answers to these questions are not readily available and simply transplanting solutions from one place to the other is unlikely to work. Adjustments in energy governance arrangements require time, through a trial and error process that has only just begun. Furthermore, the implementation of the recast Renewables Directive endows the EU with new powers of scrutiny, the exercise and implications 
of which remain to be seen. What is certain is that the implementation of the Directive will initiate a quest for solutions to the regulatory questions flagged above, both across and within EU Member States.

Addressing the gaps in knowledge identified in this article therefore could not be more timely. The imminent implementation of the Renewables and the Electricity Directives makes it critical to capture and share the lessons learned from both success and failure in those Member States that have pioneered the mainstreaming of community energy. And with states all over the world looking for ways to ensure access to affordable, reliable, sustainable, and modern energy for all, the lessons learned from this exercise are likely to resonate well beyond the boundaries of the EU. This article has argued that greater scholarly enquiry into the role of law and policy to propel community agency is in order, opening a debate and pointing towards the way in which further research should venture.

\section{ACKNOWLEDGEMENTS}

The author is grateful to Elizabeth Bomberg; Kim Bouwer; Loïc Cobut; Rowan Cruft; Elizabeth Fisher; Raphael Heffron; Kati Kulovesi; Gavin Little; Elisa Morgera, Colin Reid; David Rudolph; Antti Silvast; Helle Tegner Anker; Saskia Vermeylen, Geoffrey Wood and two anonymous reviewers for comments on earlier drafts of this article. The usual disclaimers apply. 